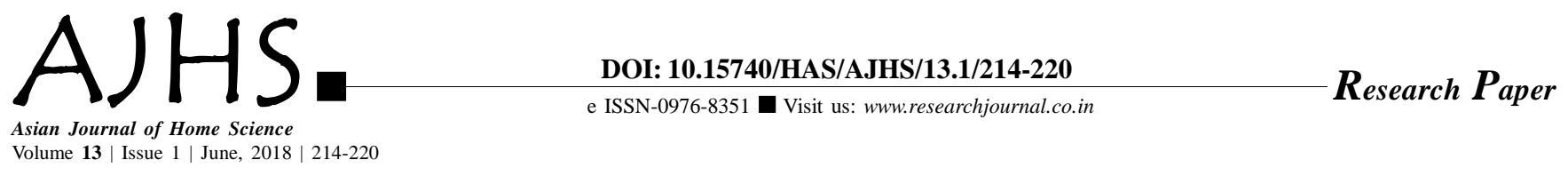

\title{
Production process of Bohey/Chhikkoo making: Traditional handicraft of Punjab
}

\author{
Lalita Rani and Kanwaljit Brar
}

Received: 05.11.2017; Revised: 05.04.2018; Accepted: 24.04.2018

See end of the paper for authors' affiliations

\section{Lalita Rani}

Department of Apparel and Textile Science, College of Home Science, Punjab Agricultural University, Ludhiana (Punjab) India

Email : dineshkumar15577@ gmail.com
ABSTRACT : The present study focused on the production process of bohey/chhikkoo the traditional handicrafts of Punjab, as these handicrafts are vanishing fast due to commercialization and changes in fashion trends. In rural Punjab, basketry weaving was mainly practiced by women to meet the domestic needs. In fact, the girls were taught to make basketry products at a very young age to prepare these as part of their trousseau. But during the present time, technological developments have made available the various types of durable and easy to care containers and baskets suitable for various end-uses at very affordable prices. As a result the traditional crafts of Punjab are fast losing their distinct individuality in terms of designs and raw materials being used for these. It is imperatives to document type of raw materials and tools that were used for making bohey/chhikkoo and their production process to preserve the traditional handicrafts for the posterity. A sample of 180 respondents of rural women, comprising of 60 women from each of the three selected districts of Malwa region namely, Ludhiana, Patiala and Bathinda, who had developed traditional handicrafts in their life-time, was selected purposively. The results showed that the presently only 13.88 per cent respondents were still practicing this craft, but made the basketry products only occasionally. Efforts in the direction of commercials of the basketry craft of Punjab need to be undertaken for the survival of this beautiful craft as been successfully done for the phulkari craft.

KEY WORDS: Bohey/chhikkoo, Production process, Raw materials, Traditional handicrafts

- HOW TO CITE THIS PAPER : Rani, Lalita and Brar, Kanwaljit (2018). Production process of Bohey/ Chhikkoo making: Traditional handicraft of Punjab. Asian J. Home Sci., 13 (1) : 214-220, DOI: 10.15740/ HAS/AJHS/13.1/214-220 Copyright@ 2018: Hind Agri-Horticultural Society.. 